Електронне наукове фахове видання "Ефективна економіка" включено до переліку наукових фахових видань України з питань економіки

(Категорія «Б», Наказ Міністерства освіти і науки України від 11.07.2019 № 975) www. economy.nayka.com.ua | № 3,2021 | 25.03.2021 p.

DOI: $\underline{10.32702 / 2307-2105-2021.3 .81}$

УдК: 311.172:330.341.1(477)

A. Podgornyj

PhD in Economics, Professor, Professor of the Department of Statistics,

Odessa National Economics University

ORCID ID 0000-0001-8281-2800

J. Olvinskaya

PhD in Economics, Associate Professor,

Head of the Department of Statistics, Odessa National Economics University

ORCID ID 0000-0002-5871-2647

O. Samotoenkova

PhD in Economics, Associate Professor,

Associate Professor of the Department of Statistics, Odessa National Economics University

ORCID ID 0000-0001-6942-8134

K. Vitkovskaja

PhD in Economics, Associate Professor,

Associate Professor of the Department of Statistics, Odessa National Economics University

ORCID ID 0000-0001-5973-1383

\title{
DEVELOPMENT OF INNOVATIVE ACTIVITY AS A FACTOR OF ECONOMIC GROWTH IN UKRAINE
}

\author{
A. 3. Підгорний, \\ к. е. н., професор, професор кафедри статистики, \\ Одеський національний економічний університет \\ Ю. О. Ольвінська, \\ к. е. н., доцент, завідувач кафедри статистики, \\ Одеський національний економічний університет \\ О. В. Самотоєнкова, \\ к. е. н., доиент, доиент кафедри статистики, \\ Одеський національний економічний університет \\ К. В. Вітковська, \\ к. е. н., дочент, дочент кафедри статистики, \\ Одеський національний економічний університет

\section{РОЗВИТОК ІННОВАЦІЙНОЇ ДІЯЛЬНОСТІ ЯК ФАКТОР ЕКОНОМІЧНОГО ЗРОСТАННЯ В УКРАЇНІ}

The article argues the role of the innovative type of development as the foundation that determines the country's economic power and its prospects in the world market. The purpose of the study is to consider the main indicators of innovative development and the rationale for rating assessing innovative activities of the country, international comparisons of the development of research and innovation. A study of literary sources and approaches to solving the problem of innovative development showed that many of its aspects require constant monitoring and analysis. Necessary 
and relevant is the further study of the state, trends, structural changes, the effectiveness of innovation in all areas of the economy. The research of the processes of innovative activity in the article was carried out in the following logical sequence: the international experience of determining the ranking of innovative countries of the world was considered; an overview of the system of international indices of innovative development; The methodology for calculating the Global Innovation Index is considered; compares the components of the Global Innovation Index for selected countries of the world and Ukraine; assessed the strengths and weaknesses of the innovation system of Ukraine. The methodological tools of the study were the methods of statistical analysis; the period of the study was selected from 2010 to 2019. The innovation activity in Ukraine was chosen as the research object, since the effectiveness of the innovation sphere is a decisive factor in ensuring the competitiveness of the economy. The article presents the results of a statistical study, which indicate that in Ukraine there is no clear tendency for the progressive development of innovative activity, a sharp drop replaces positive changes in the dynamics in innovative activity. Such fluctuations in innovation processes are explained by many reasons: $a$ reduction in financing as a percentage of GDP, a decrease in investment, a reduction in the number of industrial enterprises and others. The results of the study may be useful for management structures dealing with the restoration and development of national economies, for entrepreneurs and businessmen who are deciding on the issues of attracting investments and expanding production, and for economists dealing with problems of innovative development.

У статті аргументована роль інновачійного типу розвитку як фундаменту, щзо визначає економічну потужність країни і ї̈ перспективи на світовому ринку. Метою проведеного дослідження є розгляд основних індикаторів інновачійного розвитку та обтрунтування рейтингового оцінювання інноваційної діяльності краӥни, міжнародні зіставлення розвитку науково-дослідної та інноваційної діяльності, статистичний аналіз динаміки і структури інноваційних прочесів в економічі України, виявлення особливостей, тенденцій $i$ шляхів активізації інновачійної діяльності підприємств. Вивчення літературних джерел $і$ підходів до вирішення проблеми інноващійного розвитку показали, що багато ї̈ аспекти вимагають постійного моніторингу та аналізу. Необхідним та актуальним є подальше дослідження стану, тендениій, структурних змін, результативності інноваційної діяльності в усіх сферах економіки. Дослідження прочесів інновачійної діяльності в статті проведено в наступній логічній послідовності: розглянуто міжнародний досвід визначення рейтингу інноваційних країн світу; дан огляд системи міжнародних індексів інноваційного розвитку; розглянута методика розрахунку Глобального індексу інновацій; проведено порівняння складових Global Innovation Index за окремими країнами світу та України; дана оцінка слабких і сильних сторін інноваційної системи України. Методологічним інструментарієм проведеного дослідження стали методи статистичного аналізу, періодом дослідження обрані роки з 2010 по 2019. Об'єктом дослідження обрана інноваціийна діяльність в Украйні, оскільки ефективність інновачійної сфери $є$ вирімальним фактором забезпечення конкурентоспроможності економіки. У статті представлені результати статистичного дослідження, які свідчать про те, що в Украӥні не спостерігається чітка тенденція поступального розвитку інноваційної діяльності, позитивні зміни в динаміці змінюються різким падінням інноваційної активності. Такі коливання інноваційних прочесів пояснюються багатьма причинами: скороченням фінансування у відсотках до ВВП, зменшенням інвестицій, скороченням кількості промислових підприємств $i$ іншими. Результати проведеного дослідження можуть бути корисними для управлінських структур, щзо займаються питаннями відновлення та розвитку національної економії, для підприємиів $i$ бізнесменів, які вирішують питання залучення інвестищій і розширення виробництва, для економістів, щуо займаються проблемами інноваційного розвитку.

Keywords: Global Innovation Index; dynamics; innovation activity; innovation development; innovative enterprises; innovation performance; trends. 


\section{Ключові слова: Глобальний індекс інноваџій; динаміка; інновачійна діяльність; інноваційний розвиток; інноваційні підприємства; результативність інновацій; тенденції.}

Problem statement. The economic growth of states is ensured by the leading role of scientific and technological progress and the intellectualization of the main components of production in all areas of the economy. The share of new or improved technologies, products, equipment in which new knowledge is invested in developed countries is from 70 to $85 \%$ of GDP growth.

Currently, the development of innovative activities of enterprises, increasing the efficiency of innovative costs for the introduction of the latest technologies, and the development and production of new, competitive types of products is especially relevant for Ukraine.

Analysis of recent research and publications. Economic processes in the field of innovative development attract the attention of many foreign and domestic scientists and economists. Many works of scientists have been devoted to the issues of innovative development, the significance of innovative activity, among which V.M. Heyets, E. Libanova [4], A. M. Yerina [15], N.V. Bondarchuk [1], A.O. Knyazevich [7], O.V. Kraichuk [6], S.M. Ilyashenko [5], and others.

Identification of previously unresolved issues that are part of a common problem. Despite numerous studies of this problem, many of its aspects require constant monitoring and analysis. Necessary and relevant are further studies of the state, trends, structural changes, assessing the effectiveness of innovation activity in all areas of the national economy.

Formulation of the goals of the article. The aim of the article is to study the main indicators of innovative development and the rationale for the rating assessment of innovative activities of the country, the study of innovative processes in the Ukrainian economy, international comparisons of the development of research and innovation and innovation, a statistical analysis of the dynamics and structure of innovative costs, the development of innovative activities in all areas of the economy, including in industry, identifying features, trends and ways of enhancing the innovative activities of enterprises.

Methodology and research methods. When conducting research on indicators of innovative development and innovative processes in the Ukrainian economy, we used the methods of system analysis, which allows us to consider innovative activity as an object for research with a wide range of causal relationships; methods of statistical analysis to assess the state, identify trends and patterns of innovative development; comparative and graphic methods.

Statement of the main research material. At the present stage, the innovative type of economic development is becoming the foundation that determines the country's economic power and its prospects in the world market. The efficiency and dynamism of the innovation sphere has become a decisive factor in ensuring the competitiveness of the economy and largely determining the place of each country in the world.

In international practice, certain experience has been gained in determining the rating of innovative countries of the world, innovative development of regions, innovative activity and activity of companies.

Ukraine is represented in several international rankings that assess innovative potential, technological and innovative competitiveness. These are the Bloomberg Innovation Index, the Global Competitiveness Index, the Innovation Union Scoreboard, and the Global Talent Competitiveness Index. However, the most authoritative is the Global Innovation Index, which has been calculated since 2007 and currently represents the most comprehensive set of indicators of innovative development in different countries of the world. It was developed jointly by the International Business School INSEAD (France), Cornell University and World Intellectual Property Organization (WIPO). The rating covers more than 120 countries of the world that are at different stages of innovative development. A prerequisite for including a country in the calculation of this indicator is the presence of at least $60 \%$ of the data necessary for the calculation.

The Global Innovation Index (GII) is a multidimensional assessment of the national innovation sphere, which is entrusted with the task of determining the country's position in terms of innovation development on a global scale. The definition of this index allows you to make managerial decisions regarding the development of the country's innovative potential, the formation of competitive advantages, improving its position on a global scale, as well as identifying the strengths and weaknesses in innovation activity and minimizing them. Analysis of the global innovation index in comparison with the countries of the world allows us to identify leaders by this indicator as a whole, as well as by its individual components, and on this basis to use the foreign experience of the most progressive innovators.

To calculate the index in 2019, a set of 80 indicators was used. Of these, two-thirds are macroeconomic (quantitative) indicators from official sources of the studied countries; the remaining indicators are ratings from various international institutions and expert assessments of business leaders as part of a survey of the World Economic Forum. Since the studied countries differ in the scale of the economy, to ensure data comparability, most quantitative indicators are presented in the form of relative values of structure and intensity.

The calculation method of the Global Innovation Index is that all basic indicators are combined into two subindexes: 53 indicators characterize the country's innovative potential and form the Sub-Index Innovation Input, 27 characterize scientific and creative results and form the Sub-Index Innovation Output. 
Sub-Index Innovation Input takes into account five elements of the national economy, which create the conditions for innovation: 1) institutions; 2) human capital \& research; 3) infrastructure; 4) market sophistication; 5) business sophistication. Sub-Index Innovation Output includes two types of innovation results: 1) knowledge \& technology outputs; 2) creative outputs.

Each block is characterized by a certain number of indicators that are constantly updated in connection with the dynamism of modern innovative development.

The calculation of the index is based on combining innovative potential and opportunities for its implementation.

From a mathematical point of view, it looks like this:

$$
\mathrm{GII}=\frac{\text { Input }+ \text { Output }}{2}
$$

The closer the value is to unity, the more developed the country is in terms of innovation. At the same time, the Innovation Efficiency Ratio (IER) is determined, which is calculated by the formula:

$$
\text { IER }=\text { Output } / \text { Input }
$$

This indicator characterizes the effectiveness of innovation.

Positioning of countries in the Global ranking of innovations is carried out by:

1) according to the assessment of the Global Innovation Index on a global scale;

2) by Sub-Index Innovation Input and Sub-Index Innovation Output;

3 ) by the coefficient of innovation activity.

In 2019, 129 countries of the world took part in the calculation of GII, which is three countries more than in the previous year.

\begin{tabular}{|c|c|c|c|}
\hline & Constituents GII & Index & Ranking place \\
\hline \multicolumn{4}{|c|}{ Sub-Index Innovation Input Components } \\
\hline 1 & Institutions & 53,9 & 96 \\
\hline 2 & Human capital \& research & 35,6 & 51 \\
\hline 3 & Infrastructure & 36,0 & 97 \\
\hline 4 & Market sophistication & 43,3 & 90 \\
\hline 5 & Business sophistication & 34,8 & 47 \\
\hline & Sub-Index Innovation Input & 40,7 & 82 \\
\hline \multicolumn{4}{|c|}{ Sub-Index Innovation Output Components } \\
\hline 1 & Knowledge \& technology outputs & 34,6 & 28 \\
\hline 2 & Creative outputs & 33,5 & 42 \\
\hline & Sub-Index Innovation Output & 34,1 & 36 \\
\hline & Efficiency Ratio & 83.7 & 5 \\
\hline & Global Innovation Index & 37,4 & 47 \\
\hline
\end{tabular}

Table 1. Ukraine's positioning in the Global Innovation Index ranking in 2019

Compiled by the authors. Source: [14]

According to the results of the rating, Switzerland, Sweden, the USA, the Netherlands and the United Kingdom were among the five most innovatively developed countries. This five is not very different from 2018, with the exception of the United States, which moved from sixth to third and Singapore, which dropped lower in the ranking.

In the GII rating, Ukraine shows a rather modest innovative activity and in terms of index level in 2019 it ranked 47th in the world and 32th in Europe, by Sub-Index Innovation Input - 82 (last in Europe), Sub-Index Innovation Output - 36 (25th place in Europe). It should also be noted that in 2019 Ukraine took the second place among countries with income below the average in the GII rating. In 2018, our country was the first in terms of innovation among the countries of this group.

According to the data in Table 1, the weakest positions of the national innovation system are "Infrastructure", "Institutions" and "Market sophistication". The strengths include the following components of the Global Innovation Index - "Knowledge \& technology outputs" and "Creative outputs", which generally make up the Sub-Index Innovation Output.

An analysis of Ukraine's positions in 2019 within the framework of the constituent sub-indexes made it possible to highlight the strengths and weaknesses of innovation in Ukraine. 
Table 2. Strengths and weaknesses of the innovation system of Ukraine in 2019

\begin{tabular}{|c|l|c|}
\hline \multicolumn{1}{|c|}{ Indicator name } & Rtrengths \\
\hline \multicolumn{1}{|c|}{ Ronk } \\
\hline 1. & \multicolumn{1}{|c|}{ Pupil-teacher ratio, secondary } & 3 \\
\hline 2. & Tertiary enrolment, \% gross & 14 \\
\hline 3. & Females employed w / advanced degrees,\% & 2 \\
\hline 4. & GERD financed by abroad, & 15 \\
\hline 5. & Utility models by origin / bn PPP\$GDP & 1 \\
\hline 6. & ICT services exports, \% total trade & 11 \\
\hline 7. & Trademarks by origin / bn PPP\$ GDP & 6 \\
\hline 8. & Industrial designs by origin / bn PPP\$ GDP & 8 \\
\hline \multicolumn{2}{|c|}{ Weakness } & 110 \\
\hline 1. & Political environment & 125 \\
\hline 2. & Political \& operational stability & 107 \\
\hline 3. & Rule of law & 115 \\
\hline 4. & Ease of resolving insolvency & 120 \\
\hline 5. & Ecological sustainability & 115 \\
\hline 6. & GDP/unit of energy use & 115 \\
\hline 7. & Investment & 109 \\
\hline 8. & ICTs \& business model creation & \\
\hline
\end{tabular}

Compiled by the authors. Source: [14].

Thus, the unevenness in the development of various components of the national innovation system becomes apparent: everything related to human resources (education, availability of qualified personnel, patent activity) remains at a high level and at the same time, the institutional, regulatory environment and investment processes contribute little to the innovative development of the Ukrainian economy. This situation is due to the current economic and political situations in the country. The events taking place now in Ukraine undermined the authority of the government, and created an unfavorable investment climate, which does not help attract investors.

The next stage of the analysis was to consider how Ukraine's position in the GII rating changed for the period from 2011 to 2019.

According to the data in Table 3, for the study period, Ukraine from 60th place rose to 47th, that is, 13 positions. The worst situation was observed in 2013, when our country occupied 71st place out of 142 countries in terms of the Global Innovation Index, which is eight positions worse than the previous year. In 2018, Ukraine took 43rd place, which is the best indicator for the entire study period, which is, compared with the previous year has improved its position by seven steps. This happened due to the improvement of indicators in education and science (43rd place in the ranking), as well as business (46th place). However, the country by the next year worsened its position by four steps and dropped to 47th place in the ranking. The closest neighbors of Ukraine in 2019 were Montenegro (45), Russia (46), Georgia (48) and Turkey (49).

Table 3. Rating of Ukraine based on the Global Innovation Index

\begin{tabular}{|c|c|c|}
\hline Years & Ranking position & Number of countries in the ranking \\
\hline 2011 & 60 & 125 \\
\hline 2012 & 63 & 141 \\
\hline 2013 & 71 & 142 \\
\hline 2014 & 63 & 143 \\
\hline 2015 & 64 & 141 \\
\hline 2016 & 56 & 128 \\
\hline 2017 & 50 & 127 \\
\hline 2018 & 43 & 126 \\
\hline 2019 & 47 & 129 \\
\hline
\end{tabular}

Compiled by the authors. Source: [14].

The dynamics of the Global Innovation Index of Ukraine are clearly shown in Figure 1. As you can see, it fully repeats the trend with the rating. The highest value of the index was observed in $2018-39.5$, after which it fell to 37.4 , i.e. by more than $5 \%$, which indicates a deterioration in the country's innovative development. 


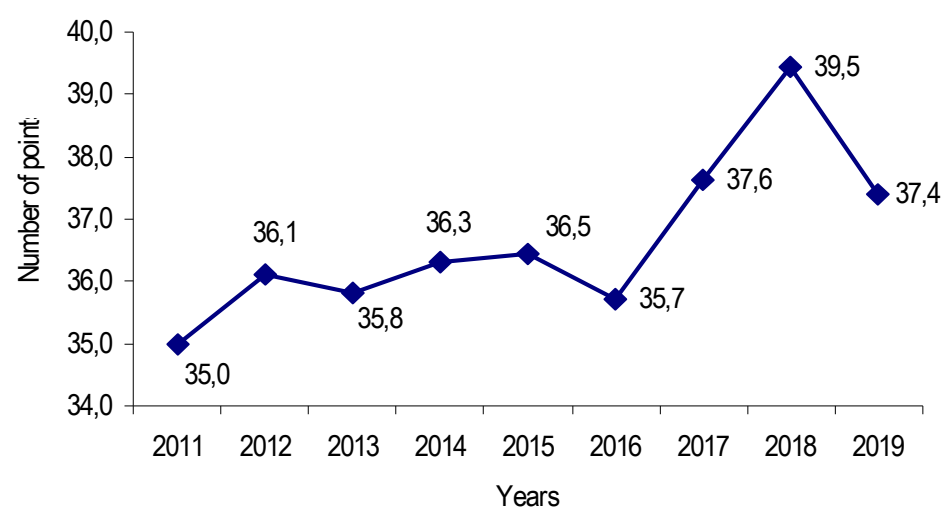

Figure 1. Dynamics of the Global Innovation Index of Ukraine Compiled by the authors. Source: [14]

Further, the authors considered Sub-Index Innovation Input and Sub-Index Innovation Output individually for a more in-depth analysis. Their dynamics for 2015-2019 presented in table 4. In addition, based on the data of subindexes, innovation efficiency factors for Ukraine were calculated.

Table 4. Dynamics of sub-indexes (Sub-Index) Global Innovation Index for Ukraine for the period 2015-2019

\begin{tabular}{|c|c|c|c|c|c|c|}
\hline \multirow{2}{*}{ Years } & \multicolumn{2}{|c|}{ Innovation Input } & \multicolumn{2}{c|}{ Innovation Output } & \multicolumn{2}{c|}{ Efficiency Ratio } \\
\cline { 2 - 7 } & Points & Rank & points & Rank & points & rank \\
\hline 2015 & 39,1 & 84 & 33,9 & 47 & 86,7 & 15 \\
\hline 2016 & 38,9 & 76 & 32,5 & 40 & 83,5 & 12 \\
\hline 2017 & 41,1 & 77 & 34,2 & 40 & 83,2 & 11 \\
\hline 2018 & 58,8 & 75 & 35,4 & 35 & 60,2 & 5 \\
\hline 2019 & 40,7 & 82 & 34,1 & 36 & 83,7 & 5 \\
\hline
\end{tabular}

Compiled by the authors. Source: [14]

As the data in Table 4 show, the values of Sub-Index Innovation Input exceed the values of Sub-Index Innovation Output, especially in 2018 (by 66\%). This is especially noticeable in the place of Ukraine, which it occupies in the world according to these indicators. This indicates that our country has significantly greater opportunities for realizing innovative potential than the available innovative resources. The innovation efficiency coefficient, which characterizes the creation of favorable conditions for innovative effectiveness throughout the entire study period, was practically unchanged. The exception is only 2018, when the innovation efficiency coefficient was the lowest for the entire study period, despite a significant improvement in Ukraine's position on the global scale of innovative development. It should also be noted that higher positioning according to the results of innovation (Sub-Index Innovation Output) compared to the potential (Sub-Index Innovation Input) provided Ukraine in 2018 and 2019 fifth place in the world in terms of innovation efficiency. Only China, Switzerland, Netherlands and Luxembourg are ahead of our country. At the same time, many countries of the world and Europe, in particular, which occupy higher places in the ranking of the Global Innovation Index, have much worse positions in terms of the coefficient of innovation. Thus, the USA takes the 18th place in the world in terms of innovation efficiency index (GII-3rd place), Germany - 11th place (GII-9th place), Poland - 51st place (GII-39th place), Russia - 80th place (GII-46th place)

Next, the dynamics of the individual components of the Global Innovation Index for Ukraine is considered, the results are presented in table 5.

Table 5. Dynamics of the components of the Global Innovation Index for Ukraine for 2015-2019

\begin{tabular}{|l|c|c|c|c|c|}
\hline \multicolumn{1}{|c|}{ Constituents GII } & $\mathbf{2 0 1 5}$ & $\mathbf{2 0 1 6}$ & $\mathbf{2 0 1 7}$ & $\mathbf{2 0 1 8}$ & $\mathbf{2 0 1 9}$ \\
\hline Institutions & 98 & 101 & 101 & 107 & 96 \\
\hline Human capital \& research & 36 & 40 & 41 & 43 & 51 \\
\hline Infrastructure & 112 & 99 & 90 & 89 & 97 \\
\hline Market sophistication & 89 & 75 & 81 & 89 & 90 \\
\hline Business sophistication & 78 & 73 & 51 & 46 & 47 \\
\hline $\begin{array}{l}\text { Knowledge \& technology } \\
\text { outputs }\end{array}$ & 34 & 33 & 32 & 27 & 28 \\
\hline \begin{tabular}{l} 
Creative outputs \\
\hline
\end{tabular} & 75 & 58 & 49 & 45 & 42 \\
\hline
\end{tabular}


As the data in Table 5 show, throughout the entire study period, the Institutions sub-indexes (96th place) and Market sophistication (90th place) remain at a consistently high level. A slight improvement was shown by the Infrastructure sub-index (from 112 place to 90). Such sub-indexes as "Business sophistication" (by 31 positions) and "Creative outputs" (by 33 positions) improved their positions more significantly. Figure 2.

We also conducted a comparative analysis of Ukraine with some EU countries and its results are presented in

It was said above that Ukraine in 2019 ranked 32nd in Europe in terms of the Global Innovation Index, which is better compared to 2015 (37th), but worse than 30th place in comparison with 2018. The closest competitors of our country in Europe were Russia (31st place) and Romania (33rd place). Therefore, we made a comparison of the main components of the Global Innovation Index for 2019 for Ukraine, Russia, Romania, and Switzerland, as this country ranks first in terms of innovative development, both in Europe and in the world as a whole. The results are presented in Figure 3.

As can be seen in Figure 3, in terms of "Institutions" and "Infrastructure", Ukraine has a worse position than all the studied countries. By such indicators as "Market sophistication" and "Business sophistication", our country is practically on the same level with Romania. However, in such positions as "Knowledge \& technology outputs" and "Creative outputs", our situation is better and we are ahead of our closest competitors, namely Russia and Romania. As for "Human capital \& research", in this indicator we are ahead only of Romania.

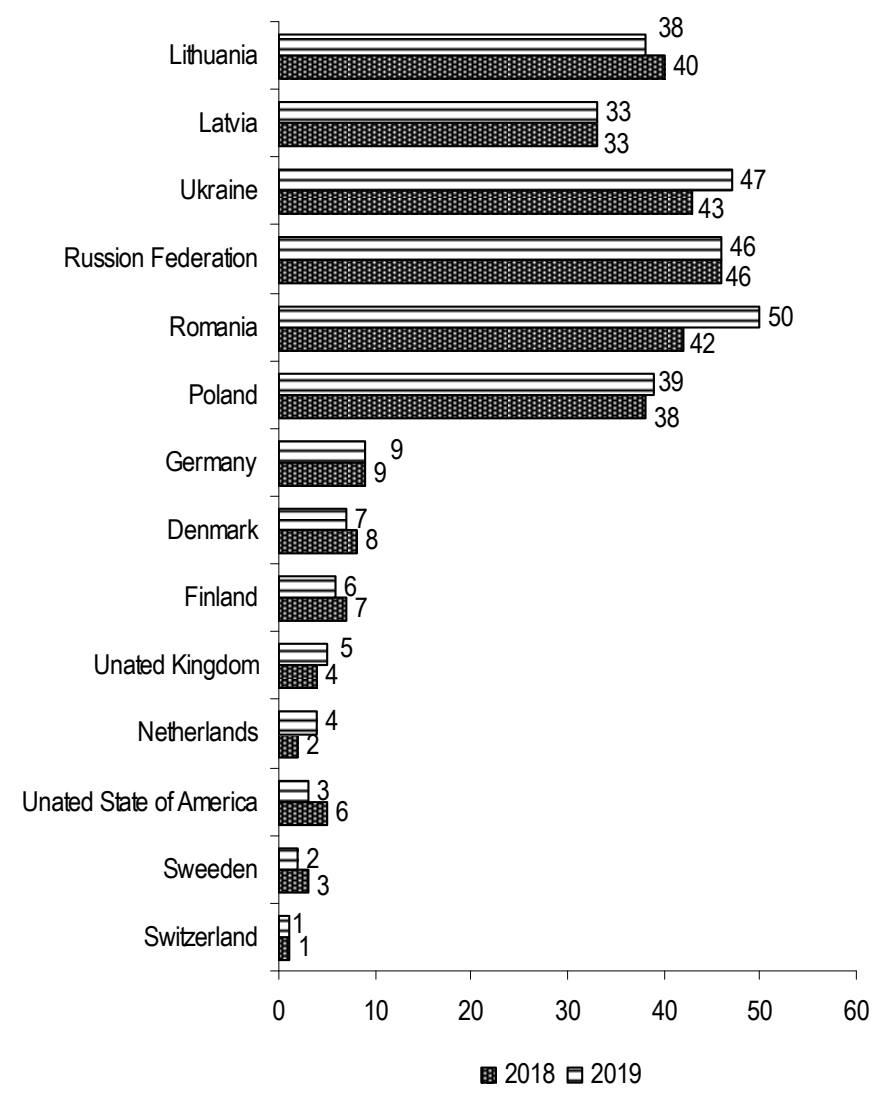

Figure 2. Dynamics of the Global Innovation Index for selected EU countries and Ukraine for 2018-2019.

Compiled by the authors. Source: [14] 


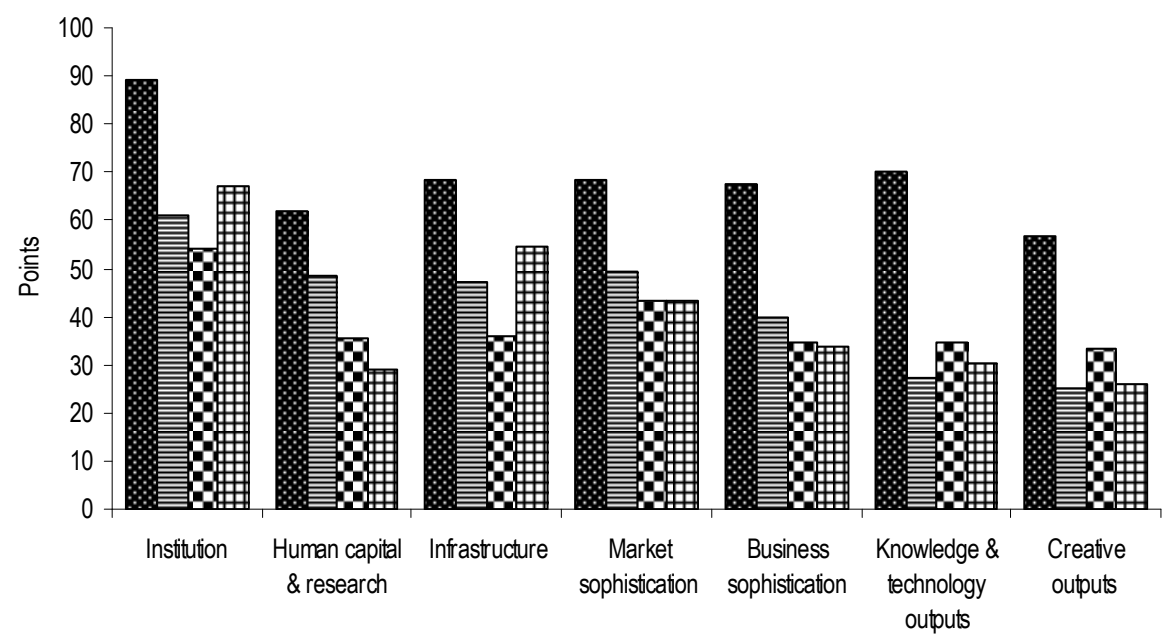

Switzerland 目 Russian Federation $\mathbf{Q}$ Ukraine $\boxplus$ Romania

Figure 3. Comparison of the components of the Global Innovation Index for 2019 for individual countries Compiled by the authors. Source: [14]

Thus, the analysis of the innovative situation at the global level using the Global Innovation Index showed that in Ukraine there are significant problems in the field of innovative development. However, it should be noted that the ratings do not give any suggestions, but only fix situations and predict the possible future direction of rating changes. In order to identify the main factors and problems that reduce the rating of Ukraine on the path to the establishment of sustainable innovative development, it is necessary to analyze the state and development of innovative activity in the country using a system of indicators based on statistics from the State Statistics Service of Ukraine, Eurostat and data from special studies.

One of the most important indicators characterizing the development of scientific and innovative activity in the state is the share of expenditures on research and development as a percentage of the gross domestic product. This indicator is also called the intensity of " $\mathrm{R} \& \mathrm{D}$ ", it reflects the degree of development of research and innovation that is carried out in the country, in terms of resources.

In order to improve the competitiveness and productivity of the European economy, the EU countries adopted the Europe 2020 strategy, one of the tasks of which is to increase public and private investment in research work by 2020 to $3 \%$ of GDP [2].

Table 6 shows the proportion of research and development work as a percentage of GDP for selected countries of the European Union and Ukraine for the period 2010-2017.

Table 6. Share of research expenditures in GDP in selected EU countries and Ukraine, \%

\begin{tabular}{|l|c|c|c|c|c|c|c|c|}
\hline \multirow{2}{*}{ Countries } & \multicolumn{9}{c|}{ Years } \\
\cline { 2 - 9 } & $\mathbf{2 0 1 0}$ & $\mathbf{2 0 1 1}$ & $\mathbf{2 0 1 2}$ & $\mathbf{2 0 1 3}$ & $\mathbf{2 0 1 4}$ & $\mathbf{2 0 1 5}$ & $\mathbf{2 0 1 6}$ & $\mathbf{2 0 1 7}$ \\
\hline EU 28 & 1,92 & 1,97 & 2,01 & 2,02 & 2,03 & 2,04 & 2,04 & 2,06 \\
\hline Bulgaria & 0,56 & 0,53 & 0,60 & 0,63 & 0,79 & 0,96 & 0,78 & 0,75 \\
\hline Hungary & 1,14 & 1,19 & 1,26 & 1,39 & 1,35 & 1,36 & 1,20 & 1,35 \\
\hline Germany & 2,71 & 2,80 & 2,87 & 2,82 & 2,87 & 2,91 & 2,92 & 3,02 \\
\hline Denmark & 2,92 & 2,94 & 2,98 & 2,97 & 2,91 & 3,06 & 3,09 & 3,05 \\
\hline Spain & 1,35 & 1,33 & 1,29 & 1,27 & 1,24 & 1,22 & 1,19 & 1,20 \\
\hline Latvia & 0,61 & 0,70 & 0,66 & 0,61 & 0,69 & 0,63 & 0,44 & 0,51 \\
\hline Lithuania & 0,78 & 0,90 & 0,89 & 0,95 & 1,03 & 1,04 & 0,84 & 0,89 \\
\hline Poland & 0,72 & 0,75 & 0,88 & 0,87 & 0,94 & 1,00 & 0,96 & 1,03 \\
\hline Romania & 0,46 & 0,50 & 0,48 & 0,39 & 0,38 & 0,49 & 0,48 & 0,50 \\
\hline Slovakia & 0,62 & 0,66 & 0,80 & 0,82 & 0,88 & 1,17 & 0,79 & 0,88 \\
\hline Slovenia & 2,06 & 2,42 & 2,57 & 2,58 & 2,37 & 2,20 & 2,01 & 1,86 \\
\hline Finland & 3,71 & 3,62 & 3,40 & 3,27 & 3,15 & 2,87 & 2,72 & 2,73 \\
\hline France & 2,18 & 2,19 & 2,23 & 2,24 & 2,23 & 2,27 & 2,22 & 2,21 \\
\hline Czech Republic & 1,34 & 1,56 & 1,78 & 1,90 & 1,97 & 1,93 & 1,68 & 1,79 \\
\hline Sweden & 3,17 & 3,19 & 3,24 & 3,27 & 3,11 & 3,23 & 3,25 & 3,37 \\
\hline Estonia & 1,58 & 2,31 & 2,12 & 1,72 & 1,43 & 1,47 & 1,25 & 1,29 \\
\hline Ukraine & $\mathbf{0 , 7 5}$ & $\mathbf{0 , 6 5}$ & $\mathbf{0 , 6 7}$ & $\mathbf{0 , 7 0}$ & $\mathbf{0 , 6 0}$ & $\mathbf{0 , 5 5}$ & $\mathbf{0 , 4 8}$ & $\mathbf{0 , 4 5}$ \\
\hline
\end{tabular}

Sources: $[8, p .62 ; 3]$ 
The data in Table 6 show that, as a whole, in the EU countries, the share of expenses for research work from 2010 to 2017 was constantly increasing. If in 2010 this share was $1.92 \%$ of GDP, in 7 years it has grown to $2.06 \%$. For individual countries shown in table 1, there are different trends. In most countries, the cost of research and development has increased in 2017 compared to 2010. This group includes Bulgaria, Denmark, Lithuania, Poland, Romania, Slovakia, Hungary, France, Sweden and the Czech Republic. Moreover, in three countries - Denmark, Germany and Sweden, the highest level of spending on science and innovation is observed, which is more than $3 \%$ of the gross domestic product, which already exceeds the level laid down in the Europe 2020 strategy. Also innovative leaders are France and Finland.

At the same time, in the group of countries, which includes Slovenia, Estonia, Spain, Latvia, research and development costs as a percentage of GDP decreased. Ukraine belongs to the same group, where, starting in 2010, there has been a tendency towards a decrease in the intensity of expenditures on research and development on the volume of GDP. It should be noted that in 2010 in Ukraine the amount of expenditure on research and development amounted to $0.75 \%$ of GDP and exceeded countries such as Bulgaria, Latvia, Poland, Romania and Slovakia in this indicator. Over 7 years, the indicator of the share of expenditures on research and development in Ukraine has significantly decreased and amounted to only $0.45 \%$ of GDP in 2017 . This is the lowest indicator of the intensity of expenditures on science and innovation in comparison with the countries of the European Union, which, of course, is reflected in the possibilities of developing innovative activities in the country. In 2018, the share of expenditures on research and development in Ukraine increased slightly, but only by $0.02 \%$ points and amounted to $0.47 \%$ of GDP, which generally did not change the overall situation. [8, p. 62].

Graphically, the dynamics of the share of expenditures on research work as a percentage of the GDP of Ukraine is presented in Fig. 4.

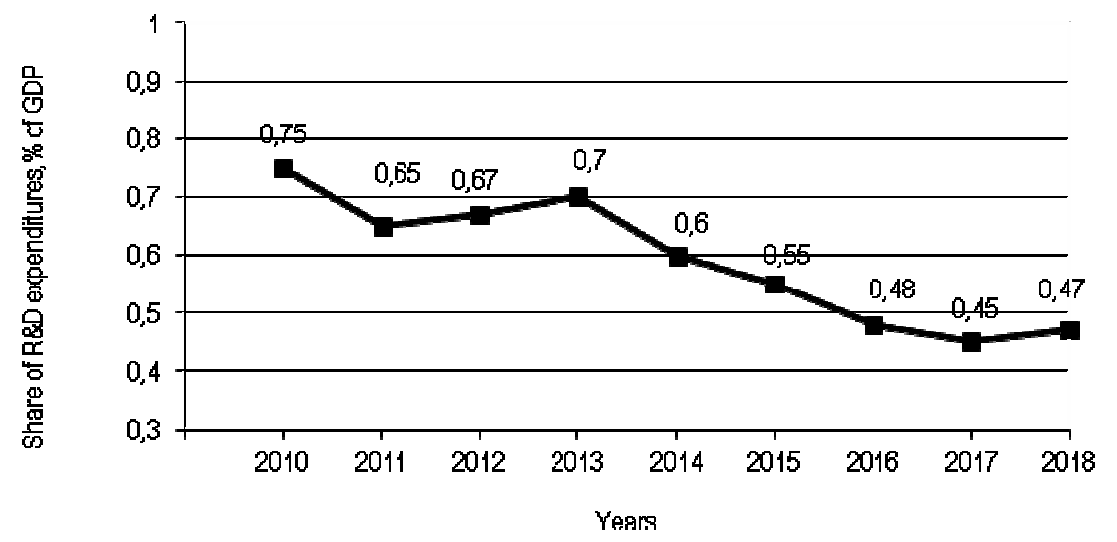

Figure 4. The proportion of expenditure on research in Ukraine, \% of GDP Compiled by the authors. Sources: [8, p. 62]

The amount of total spending on research and development in Ukraine has increased in recent years. In 2017, compared with 2016, it increased by $16.0 \%$ and amounted to 13379.3 million UAH., And in 2018 increased by another $25.4 \%$ and amounted to 16773.7 million UAH. Despite such significant growth, the share of research and development costs, as noted above, in 2018 amounted to only $0.47 \%$ of the gross domestic product.

The volume and structure of expenses for research work in Ukraine by sources of funding for 2016-2018 are shown in table 7 .

Table 7. The volume and structure of the costs of research and development by source of funding

\begin{tabular}{|l|c|c|c|c|c|c|}
\hline \multirow{2}{*}{\multicolumn{1}{|c|}{ Source of funding }} & \multicolumn{2}{c|}{ Costs of research work, million } & \multicolumn{3}{c|}{$\begin{array}{c}\text { Cost structure } \\
\text { UAH }\end{array}$} \\
\cline { 2 - 7 } & $\mathbf{2 0 1 6}$ & $\mathbf{2 0 1 7}$ & $\mathbf{2 0 1 8}$ & $\mathbf{2 0 1 6}$ & $\mathbf{2 0 1 7}$ & $\mathbf{2 0 1 8}$ \\
\hline Total & 11530,7 & 13379,3 & 16773,7 & 100,00 & 100,00 & 100,00 \\
\hline Budget funds & 3910,8 & 4896,4 & 6222,7 & 33,92 & 36,60 & 37,10 \\
\hline of which the state budget & 3700,9 & 4740,1 & 6020,9 & 32,10 & 35,43 & 35,90 \\
\hline Own funds & 1146,0 & 1340,8 & 1610,0 & 9,94 & 10,02 & 9,60 \\
\hline Public sector funds & 361,6 & 718,7 & 1141,5 & 3.14 & 5,37 & 6,80 \\
\hline Business sector funds & 3369,5 & 3007,8 & 3947,4 & 29,22 & 22,48 & 23,52 \\
\hline $\begin{array}{l}\text { Funds of Higher Education } \\
\text { Sector Organizations }\end{array}$ & 7,4 & 8,9 & 6,8 & 0,06 & 0,07 & 0,04 \\
\hline $\begin{array}{l}\text { Funds of private non-profit } \\
\text { organizations }\end{array}$ & 2,8 & 2,8 & 21,3 & 0,02 & 0,02 & 0,13 \\
\hline Means of foreign sources & 2550,3 & 3262,8 & 3642,6 & 22,12 & 24,39 & 21,72 \\
\hline Means of other sources & 182,3 & 141,1 & 181,4 & 1,58 & 1,05 & 1,08 \\
\hline
\end{tabular}

Compiled by the authors. Sources: [8, p. 49]. 
An analysis of the data in Table 7 indicates that budget funds prevail in the structure of sources of financing the costs of research and development, the share of which increased from $33.9 \%$ in 2016 to $37.1 \%$ in 2018 . At the same time, the main part is made up of the state budget: in $2018-35.9 \%$. The second place among sources of funding for research in Ukraine is occupied by funds from organizations in the business sector. However, it should be noted that the share of expenses due to this sector decreased from $29.2 \%$ in 2016 to $23.5 \%$ in 2018 . In addition, most of the expenses are from foreign sources - in 2018, $21.7 \%$. However, compared with the previous two years, the share of expenses from these funds decreased.

Among the positive changes in the structure of sources of financing the costs of research and development, an increase in the share of funds of public sector organizations from $3.1 \%$ in 2016 to $6.8 \%$ in 2018 can be noted. The proportion of financing the costs of research and development at the expense of own funds of enterprises and organizations for the period 2016-2018 changed insignificantly and is at the level of about $10 \%$.

It should be noted the extremely low share of expenses for research work at the expense of higher education organizations, in 2018 it amounted to only $0.04 \%$ of the total funding. And also a low share of expenses at the expense of private non-profit organizations, which, although it increased compared to previous years, in 2018 it amounted to only $0.13 \%$.

Graphically, the structure of expenses for research and development in Ukraine in 2018 is presented in Fig. 5.

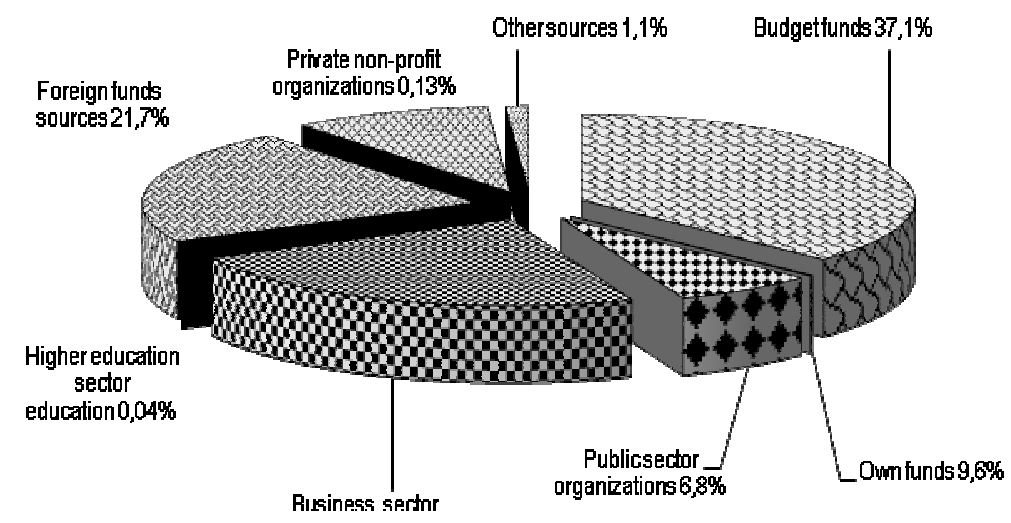

\author{
Figure 5. The structure of the costs of research and development \\ by sources of financing in Ukraine in 2018, \% \\ Compiled by the authors. Sources: [8]
}

The volume of produced and sold innovative products determines the effectiveness of innovation in the country. A relative indicator of the effectiveness of innovation is the share of new competitive products in the total volume of products sold. In 2018, in 15 countries of the European Union, the share of innovative products in the total volume of products sold exceeded 10\%. The leaders in this indicator are Slovakia (20.3\%), Spain (19.3\%), Ireland (17.0\%), Greece (16.8\%), Great Britain (15.5\%), Lithuania (14.7\%), Germany (14.0\%), and Belgium (13.6\%). The lowest proportion of innovative products in the total volume of products sold among the countries of the European Union was observed in Romania - $4.7 \%$.

Currently, in Ukraine, the level of innovation performance in comparison with EU countries is very low. By analyzing the dynamics of this indicator, we can see that in 2000 the share of innovative products in the total volume of industrial products sold was quite high and amounted to $9.4 \%$. In subsequent years, it was constantly decreasing, and in 2010 it already amounted to $3.8 \%$, and in 2018 - only $0.8 \%$. That is, in the total volume of industrial products sold, innovative products are less than $1 \%$ [12].

As we see, in two such important indicators of the development of scientific, technical and innovative activity, as the intensity of expenditures on science and innovation and the effectiveness of innovative activity, Ukraine is far behind all countries of the European Union.

The development of innovation activity in all areas of the economy and, above all, in industry is the most important resource for economic growth in Ukraine. The main tasks are attracting investment and improving the conditions for research and development, increasing the number of innovatively active enterprises and enterprises introducing innovations, creating and selling new, competitive products.

As the results of the study show, in the industry of Ukraine over the past 4 years there is no clear trend in the development of innovation. Positive changes and growth in the indicators of innovative activity of enterprises in 2016 were replaced by their sharp decline in 2017. In 2018, the innovation activity of industrial enterprises began to rise again, which is characterized by an increase in the number of innovative enterprises, an increase in the cost of innovation, an increase in the number of technological innovations and the volume of innovative products sold. Such changes and sharp fluctuations in these processes are explained by many political and economic reasons, a change in the sectoral structure of the formation of the gross domestic product, a decrease in the total number of industrial enterprises, and a drop in industrial production. 
Conclusions. The experience of the most developed countries of the world indicates that in modern conditions stable economic growth can be achieved only based on innovative development. Therefore, it is necessary to pay special attention to the state and development of innovative activity in Ukraine. Revitalization of innovation requires an integrated approach. First, state priorities for innovation in Ukraine should be clearly defined and a comprehensive set of measures for their implementation should be developed, which includes: financial incentives, training specialists, creating conditions for modernizing production, attracting research structures to implement innovative projects, and significantly improving the overall investment climate in the country.

A rating system for assessing innovative development is, of course, necessary. However, the existing system for calculating the global innovation index has certain drawbacks. In particular, from the total number of factors, indicators are used to calculate the index, which differ significantly in different countries of the world. Indeed, even Switzerland, which ranks first in the world in the global index of innovative development, has an index value of 67.24, and the lowest value from 14.49 was in Yemen. Therefore, we believe that it is necessary to review and simplify some indicators, as well as introduce some adjustment factors depending on the economic development of the country.

Promising areas should also include studies of the processes of formation and implementation of innovative projects at the enterprise, further improvement of the state innovation policy, and the search for effective mechanisms for providing innovative activities with financial resources.

\section{References.}

1. Bondarchuk, N.V. (2015), "Status and prospects of development of innovation processes in Ukraine", Visnyk Dnipropetrovs'koho derzhavnoho ahrarnoho universytetu, vol. 2, pp. 205-209.

2. Eurostat Statistics Explained (2020), "Indicators Europe 2020", available at: https://www.spbstu.ru/upload/inter/indicators-europe-2020-r-d-innovation.pdf (Accessed 26 February 2021).

3. Eurostat (2021), available at: http://ec.europa. eu/eurostat/data/database (Accessed 26 February 2021)

4. Heyets, V. (2015), Innovatsiyna Ukrayina 2020: natsional'na dopovid' [Innovative Ukraine 2020: national report]. Ukraine, Kyiv: NAN Ukrayiny.

5. Ilyashenko, S.M. Shipulina, Yu. S. and Ilyashenko, N.S. (2018), “Analysis of Ukraine's position in international rankings of innovative development", Stalyy rozvytok XXI stolittya: upravlinnya, tekhnolohiyi, modeli. Dyskusiyi 2018 [Sustainable development of the XXI century: management, technologies, models. Discussions 2018], Natsional'nyy universytet «Kyyevo-Mohylyans'ka akademiya»; Vyshcha ekonomiko-humanitarna shkola, Kyiv, Ukraine, pp. 183-195.

6. Knyazevich, A.O. and Kraychuk, O.V. (2011), Mekhanizmy upravlinnya innovatsiynym rozvytkom [Mechanisms for managing innovative development], O. Zen', Ukraine, Rivne:

7. Knyazevich, A.O. (2013), "The Global Innovation Index is an assessment of Ukraine's innovation potential”, Visnyk TNEU, vol. 2, pp.142-148.

8. State Statistics Service of Ukraine (2019), Naukova ta innovatsiyna diyal'nist' Ukrayiny [Statistical collection. Scientific and innovative activity of Ukraine], State Statistics Service of Ukraine, Kyiv, Ukraine.

9. Pysarenko, T. V. and Kvasha, T. K. (2017), Stan innovatsiynoyi diyal'nosti ta diyal'nosti u sferi transferu tekhnolohiy v Ukrayini u 2016 rotsi [The state of innovation and activity in the field of technology transfer in Ukraine in 2016], UkrINTEI, Kyiv, Ukraine.

10. Pysarenko, T. V. and Kvasha, T. K. (2019), Stan innovatsiynoyi diyal'nosti ta diyal'nosti u sferi transferu tekhnolohiy v Ukrayini u 2018 rotsi [The state of innovation and activity in the field of technology transfer in Ukraine in 2018], UkrINTEI, Kyiv, Ukraine.

12. State Statistics Service of Ukraine (2021), "Science, technology and innovation", available at: http://www.ukrstat.gov.ua. (Accessed 26 February 2021)

13. State Statistics Service of Ukraine (2017), "Survey of innovative activity in the economy of Ukraine", available at: http://www.ukrstat.gov.ua/druk/publicat/kat_u/publnauka_u.htm. (Accessed 26 February 2021)

14. Global Innovation Index (2020), “The Innovation Index 2015-2019”, available at: https://www.globalinnovationindex.org/gii-2015-2019-report (Accessed 26 February 2021)

15. Yerina, A. M. (2016), "International ratings: statistical aspects of calculation and application", Statystyka Ukrayiny, vol. 4, pp. 66-74. 